\title{
The first-line causes of alcohol-related problems: a case study among university students in Belarus
}

\author{
Menizibeya Welcome Osain*, Vladimir Pereverzev Alekseevic \\ From $1^{\text {st }}$ International Congress on Neurobiology and Clinical Psychopharmacology and European \\ Psychiatric Association Conference on Treatment Guidance \\ Thessaloniki, Greece. 19-22 November 2009
}

\section{Background}

It has been reported that the causes of alcoholism are bio-socio-psycho-faceted. The present of psychological dysfunctions which are subsequently followed by alcohol-use can result in alcoholism (second line causes of alcohol-related problems) [1,2]. But many studies have failed to recognize the fact that psycho-behavioral patterns of people (without any psychological dysfunctions) can lead to alcohol use and maybe subsequently, alcohol related problems. Stacy and coauthors have noted that cognitive motivations of a person might be necessary for many behavioral patterns (drug or alcohol use etc). The expected consequences and perception determine whether the individual starts to use alcohol or not, regularly or misuse it, consequently leading to alcohol problems or not. Expectations and motives are the proximal factors in alcohol use [2-4]. Many theories have been used to explain the pattern of alcohol use in the society. The self-effectiveness and motivational theories have been widely used to explain why people use alcohol. Alcohol users are mostly affected by the motives they prefer. For example, social factors are mostly associated with alcohol misuse. Alcohol use to reduce stress is associated with solitary drinking $[3,4]$ [5]. As in many other countries, alcohol use is a major public health problem in Belarus. The aim of this survey was to unravel the psycho-behavioral patterns of young people towards alcohol-use and to identify the major first-line causes of alcohol related problems among young adults in Belarus.

Department of Human Physiology, Belarusian state medical university, Minsk, Belarus

\section{Materials and methods}

Minsk is the capital city of Belarus with the highest population of young adults (ages 19-25) from every part of the country. A total 1599 respondents (average age 20.5 years) were administered WHO recommended questionnaire (AUDIT) [5, 6], including other standardized questions. To determine the possible psycho-behavioral patterns necessary for the causes of alcoholrelated problems, all respondents were divided into two major groups- the problem and non-problem groups. Some psycho-behavioral factors - celebrations, stress at home, days of wages, tradition, sweet properties of wine, to get drunk, use of alcohol to reduce bad mood were considered as potential factors related to alcohol problems. The probability value for significance was set at $\mathrm{p}<0.05$. Statistical calculations were performed using SPSS 16.0 version of Windows and the criteria of Pearson and Student's t-test.

\section{Results}

All in all, $87.5 \%$ alcohol users, $17.7 \%$ problem drinkers were identified. Drinking to reduce bad mood (16.4\%, p $<0.000001)$; on days of wages $(14.9 \%, \mathrm{p}<0.00001)$; for the sweet qualities of alcohol $(24.8 \%, \mathrm{p}<0.05)$; to get drunk $(26.7 \%, \mathrm{p}<0.0001)$ were reported by $87.5 \%$ alcohol users (of which $17.7 \%$ were problem drinkers) as the first-line factors of alcohol related problems.

\section{Conclusions}

According to the present study, the problem of alcohol use in the general young adult population in Belarus is high. The first-line causes of alcohol related problems were drinking to reduce bad mood, day of wages, to get drunk, for the sweet qualities of alcohol (the first-line 
psycho-behavioral patterns related to alcohol problems). Psychological dysfunctions which are subsequently followed by alcohol-use and may result in alcoholism (second line causes of alcohol-related problems) and the first-line psycho-behavioral patterns related to alcohol problems in this study are proximal factors in alcohol use and related problems.

Published: 22 April 2010

\section{References}

1. Emmanuel K, Ronald K, Gmel G, Engels R: Why do young people drink? A review of drinking motives. Clin Psych Rev 2005, 25:841-861.

2. Frone MR: Work Stress and Alcohol Use. Alcohol Res Health 1999, 23(4):284-291.

3. Stacy AW, Ames S, Sussman S, Dent CW: Implicit cognition in adolescent drug use. Psychol Addict Behav 1996, 10:190.

4. Stacy AW: Memory activation and expectancy as prospective predictors of alcohol and marijuana use. J Abnorm Psychol 1997, 106(1):61-73.

doi:10.1186/1744-859X-9-S1-S216

Cite this article as: Osain and Alekseevic: The first-line causes of alcoholrelated problems: a case study among university students in Belarus.

Annals of General Psychiatry 2010 9(Suppl 1):S216.

Submit your next manuscript to BioMed Central and take full advantage of:

- Convenient online submission

- Thorough peer review

- No space constraints or color figure charges

- Immediate publication on acceptance

- Inclusion in PubMed, CAS, Scopus and Google Scholar

- Research which is freely available for redistribution

Submit your manuscript at www.biomedcentral.com/submit 